Article

\title{
Saccharomonopyrones A-C, New $\alpha$-Pyrones from a Marine Sediment-Derived Bacterium Saccharomonospora sp. CNQ-490
}

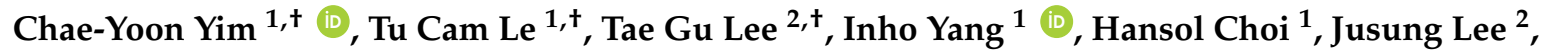 \\ Kyung-Yun Kang ${ }^{3}$, Jin Sil Lee ${ }^{4}$, Kyung-Min Lim ${ }^{4}$, Sung-Tae Yee ${ }^{3}$, Heonjoong Kang ${ }^{2,5, *}$, \\ Sang-Jip Nam ${ }^{1, *}$ and William Fenical ${ }^{6, *}$ \\ 1 Department of Chemistry and Nanoscience, Ewha Womans University, Seoul 03760, Korea; \\ yimgenie@gmail.com (C.-Y.Y.); lecamtu5789@gmail.com (T.C.L.); dbluesee@gmail.com (I.Y.); \\ hansol871231@gmail.com (H.C.) \\ 2 School of Earth and Environmental Sciences, Seoul National University, NS-80, Seoul 08826, Korea; \\ berong35@snu.ac.kr (T.G.L.); leejusung@snu.ac.kr (J.L.) \\ 3 College of Pharmacy, Sunchon National University, Suncheon 57922, Korea; \\ nms-kang@nate.com (K.-Y.K.); sungtae@sunchon.ac.kr (S.-T.Y.) \\ 4 College of Pharmacy, Ewha Womans University, Seoul 03760, Korea; wlstlf113@nate.com (J.S.L.); \\ kmlim@ewha.ac.kr (K.-M.L.) \\ 5 Research Institute of Oceanography, Seoul National University, NS-80, Seoul 08826, Korea \\ 6 Center for Marine Biotechnology and Biomedicine, Scripps Institution of Oceanography, \\ University of California-San Diego, La Jolla, CA 92093-0204, USA \\ * Correspondence: hjkang@snu.ac.kr (H.K.); sjnam@ewha.ac.kr (S.-J.N.); wfenical@ucsd.edu (W.F.); \\ Tel.: +81-2-880-5730 (H.K.); +82-10-5210-7715 (S.-J.N.); +1-858-259-3839 (W.F.) \\ + These authors contributed equally to this work.
}

Received: 2 June 2017; Accepted: 25 July 2017; Published: 1 August 2017

\begin{abstract}
Intensive study of the organic extract of the marine-derived bacterium Saccharomonospora sp. CNQ-490 has yielded three new $\alpha$-pyrones, saccharomonopyrones A-C (1-3). The chemical structures of these compounds were assigned from the interpretation of 1D, 2D NMR and mass spectrometry data. Saccharomonopyrone A (1) is the first $\alpha$-pyrone microbial natural product bearing the ethyl-butyl ether chain in the molecule, while saccharomonopyrones $B$ and $C$ possess unusual 3-methyl and a 6-alkyl side-chain within a 3,4,5,6-tetrasubstituted $\alpha$-pyrone moiety. Saccharomonopyrone A exhibited weak antioxidant activity using a cation radical scavenging activity assay with an $\mathrm{IC}_{50}$ value of $140 \mu \mathrm{M}$.
\end{abstract}

Keywords: Saccharomonospora sp.; marine natural products; $\alpha$-pyrones

\section{Introduction}

Actinobacteria are known as an abundant source of novel secondary metabolites comprising over $45 \%$ of all bioactive microbial metabolites known [1]. The recent discovery of numerous taxonomically unique marine actinomycetes, along with the isolation of structurally unprecedented secondary metabolites from these strains, illustrates marine actinomycetes as a promising source for the discovery of new natural products [2]. Saccharomonospora, a genus in the actinomycete family Pseudonocardiaceae, was first described in 1971 [3,4]. Members of the genus Saccharomonospora are interesting because they originate from diverse habitats and play an important role in the primary degradation of plant material by attacking hemicellulose [5]. Previous chemical investigations of members of this genus have led to the isolation of bioactive secondary metabolites, such as antibiotic $A B 65$, sakyomicin $E$, saccharonol $A$, antimicrobial saccharonol $B$, and piericidin $A_{3}[6,7]$. As part of our ongoing research for new secondary 
metabolites from marine actinobacteria, a Saccharomonospora bacterial strain CNQ-490 was documented. In a previous study, this strain was found to produce a novel cytotoxic alkaloid, lodopyridone A [8]. Further chemical investigation of this strain has now yielded three new natural products of the $\alpha$-pyrone class. Herein, we report the isolation and structure elucidation of saccharomonopyrones A-C (1-3) along with their biological activities (Figure 1).
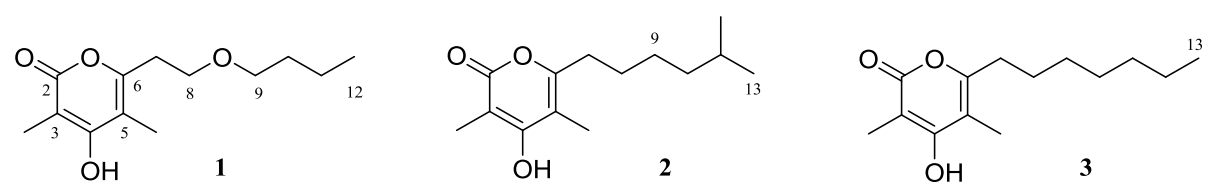

Figure 1. Structures of saccharomonopyrones A-C (1-3).

\section{Results and Discussion}

Saccharomonopyrone A (1) was obtained as a white amorphous powder. An high-resolution electrospray ionization mass spectrometry (HR-ESIMS) peak [M $+\mathrm{H}]^{+}$at $m / z 241.1446$ (calcd for 241.1434) indicated the molecular formula $\mathrm{C}_{13} \mathrm{H}_{20} \mathrm{O}_{4}$, which implied four degrees of unsaturation. UV absorption at $288 \mathrm{~nm}$ and IR absorptions at 3402,1672, and $1569 \mathrm{~cm}^{-1}$ indicated the presence of an $\alpha$-pyrone moiety.

The planar structure of $\mathbf{1}$ was confidently assigned from the interpretation of 1D and 2D NMR data. Analysis of the ${ }^{13} \mathrm{C}$ NMR (Table 1) and heteronuclear single quantum correlation (HSQC) spectroscopic data identified three oxygenated quaternary $\mathrm{sp}^{2}$ carbons $\left(\delta_{C} 155.2,164.3\right.$, and 164.5), two quaternary $\mathrm{sp}^{2}$ carbons $\left(\delta_{\mathrm{C}} 97.3\right.$ and 107.5$)$, along with two methyl singlets [3- $\mathrm{CH}_{3}\left(\delta_{\mathrm{H}} 1.82 ; \delta_{\mathrm{C}} 9.1\right)$ and $\left.5-\mathrm{CH}_{3}\left(\delta_{\mathrm{H}} 1.87 ; \delta_{\mathrm{C}} 9.9\right)\right]$, one methyl triplet $\left(\delta_{\mathrm{H}} 0.83, J=7.2 \mathrm{~Hz} ; \delta_{\mathrm{C}} 13.6\right)$ and five methylene groups $\left[\mathrm{CH}_{2}-7\left(\delta_{\mathrm{H}} 2.70, J=6.4 \mathrm{~Hz} ; \delta_{\mathrm{C}} 31.0\right) / \mathrm{CH}_{2}-8\left(\delta_{\mathrm{H}} 3.56, J=6.4 \mathrm{~Hz} ; \delta_{\mathrm{C}} 67.0\right) / \mathrm{CH}_{2}-9\left(\delta_{\mathrm{H}} 3.35, J=6.4 \mathrm{~Hz}\right.\right.$; $\left.\left.\delta_{\mathrm{C}} 69.6\right) / \mathrm{CH}_{2}-10\left(\delta_{\mathrm{H}} 1.43, \mathrm{~m} ; \delta_{\mathrm{C}} 31.1\right) / \mathrm{CH}_{2}-11\left(\delta_{\mathrm{H}} 1.26, \mathrm{~m} ; \delta_{\mathrm{C}} 18.7\right)\right]$. Interpretation of ${ }^{1} \mathrm{H}-{ }^{1} \mathrm{H}$ correlation spectroscopy (COSY) correlations allowed the construction of two spin systems: $\left[\mathrm{H}-7\left(\delta_{\mathrm{H}} 2.70\right) / \mathrm{H}-8\right.$ $\left.\left(\delta_{\mathrm{H}} 3.56\right)\right]$ and $\left[\mathrm{H}-9\left(\delta_{\mathrm{H}} 3.35\right) / \mathrm{H}-10\left(\delta_{\mathrm{H}} 1.43\right) / \mathrm{H}-11\left(\delta_{\mathrm{H}} 1.26\right) / \mathrm{H}-12\left(\delta_{\mathrm{H}} 0.83\right)\right]$. Heteronuclear multiple bond correlation (HMBC) correlations from H-8 to C-9 $\left(\delta_{C} 69.6\right)$ and from H-9 to C-8 $\left(\delta_{C} 67.0\right)$, as well as the oxygenated carbon chemical shifts of $\mathrm{C}-8$ and C-9, supported the attachment of two spin systems through an oxygen atom (Figure 2).

Table 1. ${ }^{1} \mathrm{H}$ and ${ }^{13} \mathrm{C}$ NMR spectral data for saccharomonopyrones A-C (1-3) in DMSO- $d_{6}{ }^{1}$.

\begin{tabular}{|c|c|c|c|c|c|c|}
\hline \multirow[b]{2}{*}{ No. C } & \multicolumn{2}{|c|}{ (1) } & \multicolumn{2}{|c|}{ (2) } & \multicolumn{2}{|c|}{ (3) } \\
\hline & $\delta_{C}$, Type & $\begin{array}{c}\delta_{\mathrm{H}}, \text { Mult. }{ }^{2} \\
(J \text { in Hz })\end{array}$ & $\delta_{C}$, Type & $\begin{array}{c}\delta_{\mathrm{H}}, \text { Mult. } \\
(J \text { in Hz })\end{array}$ & $\delta_{C}$, Type & $\begin{array}{c}\delta_{\mathrm{H}}, \text { Mult. } \\
(J \text { in Hz })\end{array}$ \\
\hline 2 & 164.5 & & 165.1 & & 164.6 & \\
\hline 3 & 97.3 & & 97.6 & & 97.1 & \\
\hline 4 & 164.3 & & 164.9 & & 164.4 & \\
\hline 5 & 107.5 & & 107.0 & & 106.5 & \\
\hline 6 & 155.2 & & 158.2 & & 157.8 & \\
\hline 7 & 31.0, $\mathrm{CH}_{2}$ & $2.70, \mathrm{t}(6.4)$ & $30.4, \mathrm{CH}_{2}$ & $2.47, \mathrm{t}(6.5)$ & $29.9, \mathrm{CH}_{2}$ & $2.45, \mathrm{t}(7.5)$ \\
\hline 8 & 67.0, $\mathrm{CH}_{2}$ & 3.56. t (6.4) & $27.6, \mathrm{CH}_{2}$ & $1.51, \mathrm{~m}^{3}$ & $26.8, \mathrm{CH}_{2}$ & $1.51, \mathrm{~m}$ \\
\hline 9 & $69.6, \mathrm{CH}_{2}$ & $3.35, \mathrm{t}(6.4)$ & $26.6, \mathrm{CH}_{2}$ & $1.29, \mathrm{~m}$ & $28.3, \mathrm{CH}_{2}$ & $1.26, \mathrm{~m}^{3}$ \\
\hline 10 & $31.1, \mathrm{CH}_{2}$ & $1.43, \mathrm{~m}$ & $38.4, \mathrm{CH}_{2}$ & $1.17, \mathrm{~m}$ & $28.3, \mathrm{CH}_{2}$ & $1.26, \mathrm{~m}^{3}$ \\
\hline 11 & 18.7, $\mathrm{CH}_{2}$ & $1.26, \mathrm{~m}$ & $27.8, \mathrm{CH}$ & $1.51, \mathrm{~m}^{3}$ & $31.1, \mathrm{CH}_{2}$ & $1.25, \mathrm{~m}^{3}$ \\
\hline 12 & $13.6, \mathrm{CH}_{3}$ & $0.83, \mathrm{t}(7.2)$ & $22.9, \mathrm{CH}_{3}$ & $0.85, \mathrm{~d}(6.6)$ & $22.0, \mathrm{CH}_{2}$ & $1.26, \mathrm{~m}^{3}$ \\
\hline 13 & & & $22.9, \mathrm{CH}_{3}$ & $0.85, \mathrm{~d}(6.6)$ & $13.8, \mathrm{CH}_{3}$ & $0.85, \mathrm{t}(7.1)$ \\
\hline $3-\mathrm{CH}_{3}$ & $9.1, \mathrm{CH}_{3}$ & $1.82, \mathrm{~s}$ & $9.6, \mathrm{CH}_{3}$ & $1.83, \mathrm{~s}$ & $9.1, \mathrm{CH}_{3}$ & $1.82, \mathrm{~s}$ \\
\hline $5-\mathrm{CH}_{3}$ & $9.9, \mathrm{CH}_{3}$ & $1.87, \mathrm{~s}$ & $10.3, \mathrm{CH}_{3}$ & $1.88, \mathrm{~s}$ & $9.8, \mathrm{CH}_{3}$ & $1.87, \mathrm{~s}$ \\
\hline
\end{tabular}

${ }^{1} 300 \mathrm{MHz}$ for ${ }^{1} \mathrm{H}$ NMR, $75 \mathrm{MHz}$ for ${ }^{13} \mathrm{C}$ NMR. ${ }^{2}$ Number of attached protons was deduced from 2D NMR analysis.

${ }^{3}$ Signals were overlapping. 


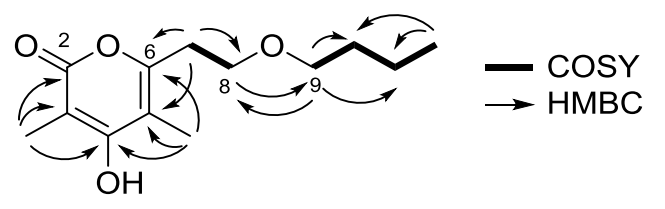

Figure 2. COSY and key HMBC correlations for saccharomonopyrone A (1).

The $\alpha$-pyrone functionality was constructed as 3,5-dimethyl-4-hydroxypyran-2-one with a side chain substituent at $\mathrm{C}-6$ by analysis of ${ }^{13} \mathrm{C}$ chemical shifts and $\mathrm{HMBC}$ correlations. HMBC correlations from $3-\mathrm{CH}_{3}$ to $\mathrm{C}-2\left(\delta_{\mathrm{C}} 164.5\right), \mathrm{C}-3\left(\delta_{\mathrm{C}} 97.3\right), \mathrm{C}-4\left(\delta_{\mathrm{C}} 164.3\right)$, and from $5-\mathrm{CH}_{3}$ to $\mathrm{C}-4, \mathrm{C}-5\left(\delta_{\mathrm{C}} 107.5\right)$, C-6 $\left(\delta_{C} 155.2\right)$, indicated the position of the methyl groups on the $\alpha$-pyrone ring. Lastly, the HMBC cross-peaks from H-7 to C- 6 and C-5 supported the connectivity of the $\alpha$-pyrone ring to the linear chain, thus completing the structure assignment of saccharomonopyrone A (1).

Saccharomonopyrone B (2) was isolated as an amorphous white powder. Its molecular formula $\mathrm{C}_{14} \mathrm{H}_{22} \mathrm{O}_{3}$ was determined by the observation of a HR-ESIMS ion peak $[\mathrm{M}+\mathrm{H}]^{+}$at $m / z 239.1651$, (calcd for 239.1642). The infrared (IR) absorption at $1673 \mathrm{~cm}^{-1}$ was assigned to a conjugated ketone functionality. The ${ }^{1} \mathrm{H}$ NMR spectrum of $\mathbf{2}$ was similar to that of $\mathbf{1}$ except for the absence of two oxygenated methylene protons and the presence of two methyl doublets. COSY NMR correlations $\left(\mathrm{H}-7\left(\delta_{\mathrm{H}} 2.47\right) / \mathrm{H}-8\left(\delta_{\mathrm{H}} 1.51\right) / \mathrm{H}-9\left(\delta_{\mathrm{H}} 1.29\right) / \mathrm{H}-10\left(\delta_{\mathrm{H}} 1.17\right), \mathrm{H}-12\left(\delta_{\mathrm{H}} 0.85\right) / \mathrm{H}-11\left(\delta_{\mathrm{H}} 1.51\right) / \mathrm{H}-13\right.$ $\left.\left(\delta_{\mathrm{H}} 0.85\right)\right)$ and $\mathrm{HMBC}$ correlations of $\mathrm{H}-12$ and $\mathrm{H}-13$ to $\mathrm{C}-10\left(\delta_{\mathrm{C}} 38.4\right)$, and from $\mathrm{H}-9\left(\delta_{\mathrm{H}} 1.29\right)$ to $\mathrm{C}-10$, and from $\mathrm{H}-10$ to $\mathrm{C}-9\left(\delta_{\mathrm{C}} 26.6\right)$ permitted the construction of the aliphatic chain as a 5-methylhexyl moiety. The linkage of the alkyl moiety to the $\alpha$-pyrone ring was secured from the HMBC correlation from $\mathrm{H}-7$ to $\mathrm{C}-6\left(\delta_{\mathrm{C}} 158.2\right)$, completing the structure assignment of saccharomonopyrone B (2) as 4-hydroxy-3,5-dimethyl-6-(5-methylhexyl)- $\alpha$-pyrone.

Saccharomonopyrone $\mathrm{C}(3)$ was also obtained as a white amorphous powder. The formula of 3 was deduced as $\mathrm{C}_{14} \mathrm{H}_{22} \mathrm{O}_{3}$ by the observation of the $[\mathrm{M}+\mathrm{H}]^{+}$ion peak at $\mathrm{m} / z 239.1665$ (calcd for 239.1642). Compound 3 had the same molecular formula as 2 . The only difference was that the ${ }^{1} \mathrm{H}$ NMR of 3 displayed a methyl triplet. The analysis of 2D NMR spectroscopic data allowed the establishment of $\mathbf{3}$ as 4-hydroxy-3,5-dimethyl-6-heptyl- $\alpha$-pyrone.

Pyrones are a well-known class of microbial secondary metabolites and are found to have a wide range of biological activities such as anti-inflammatory [9], anticancer [10], antimicrobial [11,12], anti-obesity [13,14], and antibiotic activities [15]. Previous studies on microbial sources have shown that the main producer of $\alpha$-pyrones is fungi, but $\alpha$-pyrones are also produced by plants, animals, and bacteria. Marine bacteria have also yielded $\alpha$-pyrones with interesting bioactivities, examples of which are antibiotic Sch419560 [15], germicidins, and cytotoxic violapyrones. A recent study also expanded our knowledge for the first time that pyrones can be used as signaling molecules of the bacterial cell-cell communications in the soil bacterium Pseudomonas [16]. Bacteria monitor other bacteria in their living environment by producing and responding to signaling molecules. This led to a strategy to prevent pathogenicity by blocking bacterial communication in their environment [17-19].

Saccharomonopyrones A-C (1-3) were tested on various assays such as monoamine oxidase (MAO) inhibitory, acetylcholinesterase (AChE) inhibitory, $\beta$-site amyloid precursor protein cleaving enzyme 1 (BACE1), anti-osteoporosis, cytotoxicity, anti-tyrosinase, and antibacterial activities. However, the compounds did not display any significant biological activities in these assays. Interestingly, saccharomonopyrone A (1) showed weak antioxidant activity measuring free radical scavenging activity and cation radical scavenging activity in assays with $\mathrm{IC}_{50}$ values of $911 \mu \mathrm{M}$ and $140 \mu \mathrm{M}$, respectively.

Saccharomonopyrone A (1) has an unusual ethylbutyl ether moiety attached at C-6. There are no reports of an ether moiety attached at C- 6 within the $\alpha$-pyrone class. Some similar molecules with ethyl-methyl sulfide and propyl-methyl sulfide groups were obtained as bioengineered products [20]. A similar compound possessing an ethyl chain with an acetyl end group was obtained during the 
synthesis of $\beta$-polyketones [21]. In addition, another naturally occurring and structurally similar compound is known to possess a propyl chain with a methyl carbonyl end attached at the C-6 position [22]. However, the butoxyethyl side chain in $\mathbf{1}$ is unprecedented within this class of natural products.

Nocapyrone $\mathrm{R}$ and violapyrone $\mathrm{B}$ are the most structurally related compounds of saccharomonopyrone $B(2)[11,23]$. The only difference is that nocapyrone $R$ has a methoxy group at C-3 and violapyrone B has no methyl group on C-5. Violapyrone I, structurally the most similar natural product of saccharomonopyrone C (3), also lacks the methyl group on C-5 [10].

The genus Saccharomonospora (Family Pseudonocardiaceae), with eleven known species to date, has been known since 1971 [24]. Saccharomonospora sp. CNQ-490 is a unique sediment-derived strain which produces the structurally unprecedented lodopyridones A-C $[8,25]$. Furthermore, by genome mining, this strain has been shown to possess a full biosynthetic pathway to produce a new antibiotic taromycin A through direct cloning and refactoring methods [26]. Saccharomonopyrones $\mathrm{A}-\mathrm{C}$, and previously reported natural products, lodopyridones and taromycin A, illustrate the versatile secondary metabolites producing ability of this strain. The application of a recent genetic modification method for the biosynthetic gene cluster of this strain to introduce a methyl group in natural products could lead to the successful production of new secondary metabolites [27].

\section{Materials and Methods}

\subsection{General Experimental Procedures}

The UV spectra were recorded in methanol (MeOH) on a UVS-2100 (Scinco, Seoul, Korea). The IR spectra were obtained using a Varian Scimitar Series. The NMR spectra were obtained using a Varian Inova NMR spectrometer (500 and $125 \mathrm{MHz}$ for ${ }^{1} \mathrm{H}$ and ${ }^{13} \mathrm{C}$ NMR, respectively, Varian Inc., Palo Alto, CA, USA), using the signals of the residual solvent as internal references and $\delta_{\mathrm{H}} 2.50$ and $\delta_{\mathrm{C}} 39.5 \mathrm{ppm}$ for dimethyl sulfoxide- $d_{6}$ (DMSO). High Resolution Mass spectra were determined by a JMS-AX505WA mass spectrometer (Jeol Ltd., Tokyo, Japan). Low-resolution LC-MS data were analyzed using an Agilent Technologies 6120 quadrupole LC/MS system with a reversed-phase column (Phenomenex Luna $\mathrm{C}_{18}(2) 100 \AA, 50 \mathrm{~mm} \times 4.6 \mathrm{~mm}, 5 \mu \mathrm{m}$, Phenomenex, Torrance, CA, USA) at a flow rate of $1.0 \mathrm{~mL} / \mathrm{min}$ (Agilent Technologies, Santa Clara, CA, USA). Column chromatographic separation was performed using $\mathrm{C}_{18}$ (40-63 $\mu \mathrm{m}$, ZEOprep 90, Zeochem, Zurich, Switzerland) with a gradient solvent of $\mathrm{MeOH}$ and water $\left(\mathrm{H}_{2} \mathrm{O}\right)$. The fractions were purified using reversed-phase HPLC (Waters 600S controller with 996 PDA detector (Waters Corporation, Milford, MA, USA), Phenomenex Luna $\mathrm{C}_{18}$ $(250 \mathrm{~mm} \times 10 \mathrm{~mm}, 5 \mu \mathrm{m})$ column (Phenomenex, Torrance, CA, USA)) with a mixture of acetonitrile (ACN) and $\mathrm{H}_{2} \mathrm{O}$ at flow rate of $2.0 \mathrm{~mL} / \mathrm{min}$. All chemicals were purchased from Sigma-Aldrich (Sigma-Aldrich, St. Louis, MO, USA) and used without further purification.

\subsection{Strain Isolation and Fermentation}

Actinomycete strain Saccharomonospora sp. CNQ-490 was collected from a deep sea sediment sample $2 \mathrm{~km}$ west of the Scripps pier, in La Jolla, CA, USA. The 16S rDNA sequence of this strain showed modest identity with the genus Saccharomonospora (accession number: KF301601). Strain CNQ-490 was cultured in 40-L scale using 2.5-L Ultra Yield (Thomson Instrument Company, Oceanside, CA, USA) flasks, each containing $1 \mathrm{~L}$ of the medium $(10 \mathrm{~g} / \mathrm{L}$ of soluble starch, $2 \mathrm{~g} / \mathrm{L}$ of yeast, $4 \mathrm{~g} / \mathrm{L}$ of peptone, $10 \mathrm{~g} / \mathrm{L}$ of $\mathrm{CaCO}_{3}, 20 \mathrm{~g} / \mathrm{L}$ of $\mathrm{KBr}, 8 \mathrm{~g} / \mathrm{L}$ of $\mathrm{Fe}_{2}\left(\mathrm{SO}_{4}\right)_{3} \cdot 4 \mathrm{H}_{2} \mathrm{O}$ dissolved in $1000 \mathrm{~mL}$ artificial seawater) at $25^{\circ} \mathrm{C}$ with shaking at $150 \mathrm{rpm}$. After 7 days, the broth was extracted with ethyl acetate (added ratio 1:1 of volume). The ethyl acetate layer was separated and dried with anhydrous sodium sulfate. The organic solvent was removed to yield $2.5 \mathrm{~g}$ of the organic extract. 


\subsection{Extraction and Isolation}

The crude organic extract was loaded on the $\mathrm{C}_{18}$ resin and fractionated by reversed-phase $\mathrm{C}_{18}$ (40-63 $\mu \mathrm{m}$, ZEO prep 90) flash chromatography with gradient elution (from $80 \%$ of $\mathrm{H}_{2} \mathrm{O}$ in $\mathrm{MeOH}$ to $100 \% \mathrm{MeOH}$ ) to yield eight fractions. Fractions five and six eluted with $40 \%$ and $30 \%$ of $\mathrm{H}_{2} \mathrm{O}$, respectively, were further purified by reversed-phase HPLC (Phenomenex Luna $\mathrm{C}_{18}$ column $250 \mathrm{~mm} \times 10 \mathrm{~mm}, 5 \mu \mathrm{m})$ under isocratic conditions $\left(50 \%\right.$ of $\mathrm{ACN}$ in $\mathrm{H}_{2} \mathrm{O}$ ) to give $5.7 \mathrm{mg}$ of saccharomonopyrone A (1) (retention time $15.4 \mathrm{~min}$ ), along with saccharomonopyrones B (2) (6.7 mg, retention time $45.6 \mathrm{~min}$ ) and C (3) (4.9 $\mathrm{mg}$, retention time $49.6 \mathrm{~min})$.

Saccharomonopyrone A (1): amorphous white solid, UV (MeOH) $\lambda_{\max }(\log \varepsilon) 209$ (2.53), 288 (2.49) nm; IR (KBr) $v_{\max } 3402,2941,1672,1569 \mathrm{~cm}^{-1},{ }^{1} \mathrm{H}$ and ${ }^{13} \mathrm{C}$ NMR data, Table 1 and Supplementary Materials; HRESIMS $m / z 241.1446[\mathrm{M}+\mathrm{H}]^{+}$(calcd for $\left.\mathrm{C}_{13} \mathrm{H}_{21} \mathrm{O}_{4}, 241.1434\right)$.

Saccharomonopyrone B (2): amorphous white solid, UV (MeOH) $\lambda_{\max }(\log \varepsilon) 203$ (2.53), 292 (2.32) nm; IR (KBr) $v_{\max } 3427,2940,1673,1575 \mathrm{~cm}^{-1},{ }^{1} \mathrm{H}$ and ${ }^{13} \mathrm{C}$ NMR data, Table 1 and Supplementary Materials; HRESIMS $m / z 239.1651[\mathrm{M}+\mathrm{H}]^{+}$(calcd for $\mathrm{C}_{14} \mathrm{H}_{23} \mathrm{O}_{3}, 239.1642$ ).

Saccharomonopyrone C (3): amorphous white solid, UV (MeOH) $\lambda_{\max }(\log \varepsilon) 201$ (2.53), 291 (2.20) nm; IR $(\mathrm{KBr}) v_{\max } 3395,2930,1665,1560 \mathrm{~cm}^{-1},{ }_{1}^{1} \mathrm{H}$ and ${ }^{13} \mathrm{C}$ NMR data, Table 1 and Supplementary Materials; HRESIMS $m / z 239.1665[\mathrm{M}+\mathrm{H}]^{+}$(calcd for $\mathrm{C}_{14} \mathrm{H}_{23} \mathrm{O}_{3}, 239.1642$ ).

\subsection{Bioactivity Assays}

MAO inhibitory assay [28], AChE inhibitory assay [29], BACE1 [25], anti-osteoporosis assay [30], and anti-tyrosinase assay [31] were performed following the previously published methods. Cytotoxicity tests were performed on two human kidney cancer cell lines, A498 and ACHN renal cancers, according to previously published methods [32]. Antibacterial assays were performed against seven bacterial strains including four Gram-positive (Staphylococcus epidermidis ATCC 12228, Kocuria rhizophila ATCC 9341, Bacillus subtilis ATCC 6633, Staphylococcus aureus ATCC 65381) and three Gram-negative (Escherichia coli ATCC 11775, Salmonella typhimurium ATCC 14028, Klebsiella pneumoniae ATCC 4352) strains following a previously published method [25]. The antioxidant activity was performed using the 1,1-diphenyl-2-picrylhydrazyl free radical (DPPH) as described previously with slight modification [33]. The DPPH solution $(0.45 \mathrm{mM})$ was prepared daily in a $20-\mathrm{mL}$ conical tube and kept in the dark at $4{ }^{\circ} \mathrm{C}$. The DPPH solution $(120 \mu \mathrm{L})$ was added to $60 \mu \mathrm{L}$ of sample, control, or standard solution in $70 \%$ ethanol at different concentrations. The solutions were mixed, covered, and allowed to react in the dark for $15 \mathrm{~min}$; afterward, the absorbance at $517 \mathrm{~nm}$ was read. Ascorbic acid was used as a positive control $\left(\mathrm{IC}_{50} 21.02 \pm 0.82 \mu \mathrm{M}\right)$. Data are presented as the mean values \pm standard deviation (SD) of three measurements. The free radical scavenging activity of each solution was then calculated as the percent inhibition according to the following equation:

$$
\text { Scavenging rate }(\%)=[\text { A (blank) }-\mathrm{A}(\text { sample })] / \mathrm{A}(\text { blank }) \times 100
$$

2,2'-Azino-bis(3-ethylbenzothiazoline-6-sulfonic acid) diammonium salt (ABTS) cation radical scavenging activity of the compounds were tested using the spectroscopic method described by Roberta et al. [34]. The ABTS cation radical (ABTS+) was acquired by reacting $7 \mathrm{mM}$ solution of ABTS with $2.45 \mathrm{mM}$ potassium persulfate reaction. The mixture was left to stand in the dark at room temperature for 12-16 h before use. Prior to the assay, the ABTS radical cation solution was diluted with ethyl alcohol to an absorbance of $0.750 \pm 0.05$ at $734 \mathrm{~nm}$. The ABTS+ solution was then added to each sample, standard, and control solution. Ascorbic acid was used as a positive control $\left(\mathrm{IC}_{50} 13.01 \pm 0.21 \mu \mathrm{M}\right)$. Data are presented as the mean values \pm standard deviation (SD) of the three measurements. The extent of decolorization is calculated as a percent reduction in absorbance. The percentage of cation radical scavenging was computed using the following equation: 
Scavenging rate $(\%)=[$ A (blank $)-\mathrm{A}($ sample $)] / \mathrm{A}($ blank $) \times 100$

\subsection{Statistical Analyses}

Statistical analyses for DPPH and ABTS cation radical scavenging activities were performed using GraphPad Prism 5 (GraphPad Software, Inc., La Jolla, CA, USA). The nonlinear regression was used to determine the dose-response inhibition. Results are expressed as means \pm standard deviation of three independent experiments.

\section{Conclusions}

Three new $\alpha$-pyrones, saccharomonopyrones A-C (1-3), were isolated from the marine sediment-derived bacterium Saccharomonospora sp. strain CNQ-490. Saccharomonopyrones A-C (1-3) are 3,4,5,6-tetra-subtituted $\alpha$-pyrones. Saccharomonopyrone A is unusual in having an ether moiety attached at C-6, observed for the first time in this class of natural products. Analysis of the tetra-substituted $\alpha$-pyrone biosynthetic gene cluster from this strain may provide an opportunity to discover diverse $\alpha$-pyrone analogues.

Supplementary Materials: The following are available online at www.mdpi.com/1660-3397/15/8/239/s1; ${ }^{1} \mathrm{H},{ }^{13} \mathrm{C}$ and 2D NMR spectroscopic data of saccharomonopyrones A-C (1-3).

Acknowledgments: This work was supported by the Marine Biotechnology Program, the Ministry of Oceans and Fisheries, Korea and by the National Research Foundation of Korea grants (NRF-2012M1A5A1054307), the Ministry of Education, Science and Technology, Korea., by Suncheon Research Center for Natural Medicines (to SJN), and by the US National Cancer Institute (NIH) under grant R37 CA044848 (to WF).

Author Contributions: C.-Y.Y. did large culture, isolated the compounds, and wrote the manuscript. T.C.L. elucidated the chemical structure and wrote the manuscript. T.G.L. performed bioassays and wrote the manuscript. J.L. and I.Y. contributed NMR analysis and surveyed the literature. H.C. did large culture and collected NMR spectroscopic data. J.S.L. and K.-M.L. performed anti-tyrosinase assay. K.-Y.K. and S.-T.Y. performed anti-oxidation assay. H.K. was the project leader for bioassays and analysis. S.-J.N. was the project leader for guiding the experiments of chemical analysis and writing manuscript. W.F. was the project leader and contributed microbial strain and guided the manuscript.

Conflicts of Interest: The authors declare no conflict of interest.

\section{References}

1. Bérdy, J. Bioactive microbial metabolites. J. Antibiot. 2005, 58, 1-26. [CrossRef] [PubMed]

2. Jensen, P.R.; Mincer, T.J.; Williams, P.G.; Fenical, W. Marine actinomycete diversity and natural product discovery. Antonie Van Leeuwenhoek 2005, 87, 43-48. [CrossRef]

3. Liu, Z.; Li, Y.; Zheng, L.-Q.; Huang, Y.-J.; Li, W.-J. Saccharomonospora marina sp. nov., isolated from an ocean sediment of the East China Sea. Int. J. Syst. Evol. Microbiol. 2010, 60, 1854-1857. [CrossRef] [PubMed]

4. Veyisoglu, A.; Sazak, A.; Cetin, D.; Guven, K.; Sahin, N. Saccharomonospora amisosensis sp. nov., isolated from deep marine sediment. Int. J. Syst. Evol. Microbiol. 2013, 63, 3782-3786. [CrossRef]

5. Meier-Kolthoff, J.P.; Lu, M.; Huntemann, M.; Lucas, S.; Lapidus, A.; Copeland, A.; Pitluck, S.; Goodwin, L.A.; Han, C.; Tapia, R.; et al. Genome sequence of the chemoheterotrophic soil bacterium Saccharomonospora cyanea type strain (NA-134(T)). Stand. Genom. Sci. 2013, 9, 28-41. [CrossRef] [PubMed]

6. Tamura, A.; Takeda, I. Antibiotic AB-65, a new antibiotic from Saccharomonospora viride. J. Antibiot. 1975, 28, 395-397. [CrossRef] [PubMed]

7. Singh, B.; Parshad, R.; Khajuria, R.K.; Guru, S.K.; Pathania, A.S.; Sharma, R.; Chib, R.; Aravinda, S.; Gupta, V.K.; Khan, I.A.; et al. Saccharonol B, a new cytotoxic methylated isocoumarin from Saccharomonospora azurea. Tetrahedron Lett. 2013, 54, 6695-6699. [CrossRef]

8. Maloney, K.N.; Macmillan, J.B.; Kauffman, C.A.; Jensen, P.R.; Dipasquale, A.G.; Rheingold, A.L.; Fenical, W. Lodopyridone, a structurally unprecedented alkaloid from a marine actinomycete. Org. Lett. 2009, 11, 5422-5424. [CrossRef] [PubMed]

9. Lee, H.-S.; An, B.-J.; Kim, H.J.; Cho, Y.H.; Kim, D.I.; Jang, J.Y.; Kwak, J.H.; Lee, H.-S.; Lee, Y.-J.; Lee, J.S.; et al. Anti-Inflammatory Effect of Violapyrones B and C from a Marine-derived Streptomyces sp. Nat. Prod. Sci. 2015, 21, 251-254. [CrossRef] 
10. Shin, H.; Lee, H.-S.; Lee, J.; Shin, J.; Lee, M.; Lee, H.-S.; Lee, Y.-J.; Yun, J.; Kang, J. Violapyrones H and I, New Cytotoxic Compounds Isolated from Streptomyces sp. Associated with the Marine Starfish Acanthaster planci. Mar. Drugs 2014, 12, 3283-3291. [CrossRef]

11. Zhang, J.; Jiang, Y.; Cao, Y.; Liu, J.; Zheng, D.; Chen, X.; Han, L.; Jiang, C.; Huang, X. Violapyrones A-G, $\alpha$-pyrone derivatives from Streptomyces violascens isolated from Hylobates hoolock feces. J. Nat. Prod. 2013, 76, 2126-2130. [CrossRef] [PubMed]

12. Bertin, M.J.; Demirkiran, O.; Navarro, G.; Moss, N.A.; Lee, J.; Goldgof, G.M.; Vigil, E.; Winzeler, E.A.; Valeriote, F.A.; Gerwick, W.H. Kalkipyrone B, a marine cyanobacterial $\gamma$-pyrone possessing cytotoxic and anti-fungal activities. Phytochemistry 2016, 122, 113-118. [CrossRef] [PubMed]

13. Chu, M.; Mierzwa, R.; Xu, L.; He, L.; Terracciano, J.; Patel, M.; Zhao, W.; Black, T.A.; Chan, T.-M. Structure of Sch 419560, a novel $\alpha$-pyrone antibiotic produced by Pseudomonas fluorescens. J. Antibiot. 2002, 55, 215-218. [CrossRef] [PubMed]

14. Koyama, T.; Kawazoe, Y.; Iwasaki, A.; Ohno, O.; Suenaga, K.; Uemura, D. Anti-obesity activities of the yoshinone $\mathrm{A}$ and the related marine $\gamma$-pyrone compounds. J. Antibiot. 2016, 69, 348-351. [CrossRef] [PubMed]

15. Inuzuka, T.; Yamamoto, K.; Iwasaki, A.; Ohno, O.; Suenaga, K.; Kawazoe, Y.; Uemura, D. An inhibitor of the adipogenic differentiation of 3T3-L1 cells, yoshinone A, and its analogs, isolated from the marine cyanobacterium Leptolyngbya sp. Tetrahedron Lett. 2014, 55, 6711-6714. [CrossRef]

16. Brachmann, A.O.; Brameyer, S.; Kresovic, D.; Hitkova, I.; Kopp, Y.; Manske, C.; Schubert, K.; Bode, H.B.; Heermann, R. Pyrones as bacterial signaling molecules. Nat. Chem. Biol. 2013, 9, 573-578. [CrossRef] [PubMed]

17. Taga, M.E.; Bassler, B.L. Chemical communication among bacteria. Proc. Natl. Acad. Sci. USA 2003, 100, 14549-14554. [CrossRef] [PubMed]

18. Bassler, B.L.; Losick, R. Bacterially speaking. Cell 2006, 125, 237-246. [CrossRef] [PubMed]

19. Bassler, B.L. Small Talk. Cell 2002, 109, 421-424. [CrossRef]

20. Huitt-Roehl, C.R.; Hill, E.A.; Adams, M.M.; Vagstad, A.L.; Li, J.W.; Townsend, C.A. Starter unit flexibility for engineered product synthesis by the nonreducing polyketide synthase PksA. ACS Chem. Biol. 2015, 10, 1443-1449. [CrossRef] [PubMed]

21. Tian, J.-F.; Yu, R.-J.; Li, X.-X.; Gao, H.; Guo, L.-D.; Tang, J.-S.; Yao, X.-S. ${ }^{1} \mathrm{H}$ and ${ }^{13} \mathrm{C}$ NMR spectral assignments of 2-pyrone derivatives from an endophytic fungus of sarcosomataceae. Magn. Reson. Chem. 2015, 53, 866-871. [CrossRef] [PubMed]

22. Douglas, J.L.; Money, T. Pyrone studies. Linear $\alpha$-pyrone route to protected $\beta$-polyketones. Can. J. Chem. 1968, 46, 695-700. [CrossRef]

23. Kim, Y.; Ogura, H.; Akasaka, K.; Oikawa, T.; Matsuura, N.; Imada, C.; Yasuda, H.; Igarashi, Y. Nocapyrones: $\alpha$ - and $\gamma$-pyrones from a marine-derived Nocardiopsis sp. Mar. Drugs 2014, 12, 4110-4125. [CrossRef] [PubMed]

24. Nonomura, H.; Ohara, Y. Distribution of actinomycetes in soil. X. New genus and species of monosporic actinomycetes. J. Ferment. Techonol. 1971, 49, 895-903.

25. Le, T.C.; Yim, C.-Y.; Park, S.; Katila, N.; Yang, I.; Song, M.C.; Yoon, Y.J.; Choi, D.-Y.; Choi, H.; Nam, S.-J.; et al. Lodopyridones B and C from a marine sediment-derived bacterium Saccharomonospora sp. Bioorg. Med. Chem. Lett. 2017, 27, 3123-3126, in press. [CrossRef] [PubMed]

26. Yamanaka, K.; Reynolds, K.A.; Kersten, R.D.; Ryan, K.S.; Gonzalez, D.J.; Nizet, V.; Dorrestein, P.C.; Moore, B.S. Direct cloning and refactoring of a silent lipopeptide biosynthetic gene cluster yields the antibiotic taromycin A. Proc. Natl. Acad. Sci. USA 2014, 111, 1957-1962. [CrossRef] [PubMed]

27. Koryakina, I.; McArthur, J.B.; Draelos, M.M.; Williams, G.J. Promiscuity of a modular polyketide synthase towards natural and non-natural extender units. Org. Biomol. Chem. 2013, 11, 4449-4458. [CrossRef] [PubMed]

28. Lee, H.W.; Choi, H.; Nam, S.-J.; Fenical, W.; Kim, H. Potent Inhibition of Monoamine Oxidase B by a Piloquinone from Marine-Derived Streptomyces sp. CNQ-027. J. Microbiol. Biotechnol. 2017, 27, 785-790. [CrossRef] [PubMed]

29. Kim, H.; Yang, I.; Patil, R.S.; Kang, S.; Lee, J.; Choi, H.; Kim, M.-S.; Nam, S.-J.; Kang, H. Anithiactins A-C, modified 2-phenylthiazoles from a mudflat-derived Streptomyces sp. J. Nat. Prod. 2014, 77, 2716-2719. [CrossRef] [PubMed] 
30. Kim, H.; Kim, K.-J.; Yeon, J.-T.; Kim, S.H.; Won, D.H.; Choi, H.; Nam, S.-J.; Son, Y.-J.; Kang, H. Placotylene A, an inhibitor of the receptor activator of nuclear factor- $\mathrm{kB}$ ligand-induced osteoclast differentiation, from a Korean sponge Placospongia sp. Mar. Drugs 2014, 12, 2054-2065. [CrossRef] [PubMed]

31. Kim, K.; Leutou, A.S.; Jeong, H.; Kim, D.; Seong, C.N.; Nam, S.-J.; Lim, K.-M. Anti-pigmentary effect of (-)-4-hydroxysattabacin from the marine-derived bacterium Bacillus sp. Mar. Drugs 2017, 15, 138. [CrossRef] [PubMed]

32. Leutou, A.S.; Yang, I.; Kang, H.; Seo, E.K.; Nam, S.-J.; Fenical, W. Nocarimidazoles A and B from a Marine-Derived Actinomycete of the Genus Nocardiopsis. J. Nat. Prod. 2015, 78, 2846-2849. [CrossRef] [PubMed]

33. Thomas, J.H.; Priyadarshini, G.; Michael, T. High-throughput micro plate assays for screening flavonoid content and DPPH-scavenging activity in sorghum bran and flour. J. Sci. Food Agric. 2012, 92, 2326-2331.

34. Roberta, R.; Nicoletta, P.; Anna, P.; Ananth, P.; Min, Y.; Catherine, R.E. Antioxidant activity applying an improved ABTS radical cation decolorization assay. Free Radic. Biol. Med. 1999, 26, 1231-1237.

(C) 2017 by the authors. Licensee MDPI, Basel, Switzerland. This article is an open access article distributed under the terms and conditions of the Creative Commons Attribution (CC BY) license (http:// creativecommons.org/licenses/by/4.0/). 